\title{
Effect of Bitter Kola (Garcinia kola) as A Dietary Additive on the Performance of Broiler Chicks
}

\author{
Aliyu Abdullahi Mohammed (Corresponding author) \\ Dept. of Animal Science, Usmanu Danfodiyo University, Sokoto \\ PMB 2346, Sokoto, Nigeria \\ Tel: 234-802-790-9029Ｅ-mail: aliyuabdullahimohammed@gmail.com
}

Mundi Attai AbdulMalik

Dept. of Animal Science, Usmanu Danfodiyo University, Sokoto

PMB 2346, Sokoto, Nigeria

Tel: 234-803-294-2759 E-mail: mundiabdulmalik@yahoo.com

Received: January 18, 2013 Accepted: March 11, $2013 \quad$ Published: December 25, 2013

doi:10.5296/jee.v4i2.3075 URL: http://dx.doi.org/10.5296/jee.v4i2.3075

\begin{abstract}
The study was conducted to assess the performance of broiler chicks ( 0-4 weeks) of age fed sun dried ground bitter kola (Garcinia kola) as a dietary additive at $5 \mathrm{~g} / \mathrm{Kg}$ diet (BK 5), $10 \mathrm{~g} / \mathrm{Kg}$ diet (BK 10) in addition to a control diet with no Garcinia kola (BK 0). Sixty Three (63) Marshall broiler strain chicks of mixed sexes were used for the experiment. Paired t- test was used to analyze the data. There were differences $(\mathrm{p}<0.05)$ in terms of feed gain ratio (FGR) and cost of feed per $\mathrm{Kg}$ gain (CFG) between birds on BK 0 and those on BK 5. Birds on BK 5 had better FGR and CFG. Comparing birds on BK0 and BK 10 showed differences $(\mathrm{P}<0.05)$ in terms of final weight $(\mathrm{FW})$, weight gain $(\mathrm{WG})$ and average daily weight gain (ADWG). Birds on BK 10 had higher FW, WG and ADWG. Also birds on BK 10 had slightly better $(\mathrm{P}>0.05)$ FGR than birds on BK 0 . Birds on BK 0 however had slightly lower $(\mathrm{P}>0.05)$ CFG than birds on BK 10. No differences exist in all the performance parameters analyzed between birds on BK 5 and those on BK 10 treatments. Though, birds on BK 5 had slightly higher ( $p>0.05$ ) FW, WG and ADWG. Sun dried ground bitter kola could be used as an additive in broiler diets at $5 \mathrm{~g} / \mathrm{Kg}$ diet.
\end{abstract}

Keywords: Bitter kola, Phytogenic, Feed additive, Broiler, Chick, Diet 


\section{Introduction}

In recent years, local plant materials are tried as additives in poultry feed to overcome major problems in poultry industry, like environmental effects on digestibility and feed utilization (Sayda et al., 2012). Phytogenic feed additives have attracted increasing interest as an alternative feeding strategy to replace antibiotic and or inorganic growth promoters. This has occurred especially in the European Union, where antibiotic has been banned completely from use as additive in livestock feeds since 2006, because of a suspected risk of generating microbiota with increase resistance to the antibiotic used for therapy in human and animals (Windisch et al., 2008). Estimates by WHO, (2002) reports that the majority of the rising antimicrobial resistance problem in human medicine is due to the overuse and misuse of antimicrobials. The best known examples are the food-borne pathogenic bacteria Salmonella and Campylobacter and the commensal (harmless in healthy persons and animals) bacteria Enterococcus. Research has shown that resistance of these bacteria to classic treatment in humans is often a consequence of the use of certain antimicrobials in agriculture. Some of the newly-emerging resistant bacteria in animals are transmitted to humans mainly via meat and other food of animal origin or through direct contact with farm animals. Increasing animal body weight gain and improving feed conversion ratio are measures that can indicate increased profitability for the producer. The inclusion of organic products may positively affect these measures in poultry (Flint and Garner, 2009).

Whereas the inclusion of antibiotics in livestock feed is aimed at eliminating or reducing specific or general bacterial populations in a preventive manner in order to improve feed utilization and hence profit, the addition of organic products or phytogenics to feedstuffs may be a viable substitute to increase the profitability of animal agriculture (Flint and Garner, 2009). In addition, in most of African villages, modeled feed additives that could be used in the formulation of poultry feeds are not accessible.

Phytogenic feed additives are plant extracts or materials which may have beneficial effect on animal production and health. A large variety of the plants materials have properties which could potentially improve feed intake, digestion, feed conversion and body weight gain (Lovkova et al., 2001; Williams and Losa, 2001; Ertas et al., 2005). The mode of action of these feed additives is not completely clear. They have antimicrobial, antiviral, antioxidant and many other biological activities (Ertas et al., 2005; Cross et al., 2007). They act as digestibility enhancers, stimulating the secretion of endogenous digestive enzymes (Williams and Losa, 2001; Lee et al., 2003). These traits made phytogenic additives a promising group of growth promoters that are presently been tried in the animal feed industry. Consequently, the animal feed industry, exposed to increasing consumer pressure to reduce the use of animal growth promoters ( mostly inorganic) in poultry diets, has to find alternative feed additives (Humphrey et al., 2002; Botsoglou et al., 2004 ). Scientific evidence exist that herbs and plant extracts stimulate the growth of beneficial bacteria and minimize pathogenic bacteria activity in the gastrointestinal tract of poultry (Gill, 1999; Langhout, 2000; Wenk, 2000). Literature on using phytogenics especially bitter kola as a feed additive is still limited and mostly in conclusive. 
Bitter kola (Garcinia kola) tree belong to the botanical family of Guttiferae (Plowden, 1992). It is a rain forest tree crop, well cultivated through West Indies, West and Central Africa (Iwu, 1993). It is an evergreen tree which can grow up to 30m high but usually up to about $12-15 \mathrm{~m}$. The bitter kola fruits are reddish yellow when ripe. Each fruit contains about 6-8 smooth elliptically shaped seeds with brown coat. Bitter kola is popularly called in major Nigerian languages as 'Namijin goro' in Hausa, 'Orogbo' in Yoruba and 'Agbilu' in Igbo. Bitter kola is known to have an elaborate complex mixture of phenolic compounds including bioflavonoids, xanthones and benzophenones (Iwu et al., 1990). The bioflavonoid posses anti-inflammatory, anti-microbial, anti-viral and anti-diabetic properties (Adedeji et al., 2006). Adegboye et al., (2008) tested for the presence of alkaloids, steroids, cardiac glycosides, flavonoids, tannins, saponins and reducing sugar in bitter kola. All the phytochemical compounds tested for were found present except alkaloids. Other reports on phytochemical compounds isolated from bitter kola include oleoresin (Onyade et al., 1998), tannins, saponins, alkaloids, cardiac glycosides (Ebana et al., 1991). Biflavonoids such as kolaflavone and 2-hydroxybi-flavonols (Okunji and Iwu, 1991; Terashima et al., 1999; Okunji et al., 2002). Also bitter kola was reported to contain in g/100g Tannin- $0.342 \pm 0.00$, Oxalate- $0.423 \pm 0.00 \mathrm{~g}$, Phytate- $0.570 \pm$ 0.05 , Trypsin inhibitor- $0.370 \pm 0.12$, Phenol- $0.147 \pm 0.00$, Saponin- $2.471 \pm 0.00$, Alkaloids$0.647 \pm 0.20$, flavonoids $2.041 \pm 0.30$ and glycosides $3.421 \pm 0.00$ (Adesuyi et al., 2012).

The major active constituents (alkaloids and flavonoids) of bitter kola were reported to stimulate an increase in gastric acid secretion (Oluwole and Obtatomi, 1991). Bitter kola was reported to contain $0.58 \%$ crude protein, $0.10 \%$ Crude fibre, $3 \%$ ether extract, $5 \%$ crude ash and $72.72 \%$ Nitrogen free extract (Ibekwe and Orok, 2010 ). Odebunmi et al., (2009) reported fresh bitter kola to have $39.52 \pm 0.06 \%$ dry matter, $4.51 \pm 0.56 \%$ crude fat, $2.48+$ $0.10 \%$, crude protein, $0.79 \pm 0.005 \%$ ash, $5.23 \pm 0.16 \%$ Crude fibre and $35.64 \%$ total carbohydrates. The following mineral compositions from bitter kola were also reported in $\mathrm{mg} / \mathrm{Kg}: \quad \mathrm{K}-722.10 \pm 0.00, \quad \mathrm{Ca}-67.07 \pm 0.12, \mathrm{Mg}-114.83 \pm 3.47, \quad \mathrm{Fe}-6.10 \pm 0.43, \mathrm{Zn}-$ $2.30 \pm 0.08$, Mn- not detectable, P-188.57 \pm 0.37 (Odebunmi et al., 2009). Adesuyi et al., (2012) also reported the following proximate chemical composition for bitter kola: Moisture content- $7.2 \pm 0.08 \%$, Crude protein- $1.86 \pm 0.15 \%$, Crude fibre- $1.23 \pm 0.15 \%$, Ash- $0.47 \pm$ $0.09 \%$, Crude fat $0.19 \pm 0.32 \%$, Carbohydrate- $88.30 \pm 0.08 \%$.

Dried bitter kola seeds were used as a growth promoter in the diet of broiler chicks at $2.5 \%$ (25g/Kg diet), $5 \%(50 \mathrm{~g} / \mathrm{Kg}$ diet), $7.5 \%(75 \mathrm{~g} / \mathrm{Kg}$ diet $)$ and $10 \%(100 \mathrm{~g} / \mathrm{Kg}$ diet $)$ level of inclusion. Feed efficiency was highest $(\mathrm{p}<0.05)$ in $2.5 \%$ level of inclusion and lowest $(\mathrm{p}<0.05)$ in 5 and $7.5 \%$ inclusion levels (Adedeji et al., 2006). The performance and egg quality parameters of laying hens fed different inclusion levels of bitter kola were also monitored by Adedeji et al (2008). The authors fed different diets containing bitter kola at $10 \mathrm{~g} / \mathrm{kg}$ diet, $20 \mathrm{~g} / \mathrm{kg}$ diet, $40 \mathrm{~g} / \mathrm{kg}$ diet and $80 \mathrm{~g} / \mathrm{kg}$ diet weight of feed in addition to a control diet without bitter kola inclusion. The trial lasted for 8 weeks. There were significant differences $(\mathrm{p}<0.05)$ in hen- day production and albumen weight. The best hen-day production and albumen weight were obtained from $10 \mathrm{~g} / \mathrm{kg}$ dietary inclusion of bitter kola. Moreover bitter kola did not cause any deleterious effect to the birds even at $80 \mathrm{~g} / \mathrm{kg}$ diet (Adedeji et al., 2008). 
The objectives of the study were to assess the growth performance and the cost of feed per $\mathrm{Kg}$ weight gain of broiler chicks on various levels of dietary additive of bitter kola.

\section{Materials and Methods}

\subsection{Experimental Location}

The experiment was carried out at the poultry production section of Sokoto State veterinary center located at Aliyu Jodi road in Sokoto State metropolis in September, 2012. Sokoto State has a mean annual maximum and minimum temperature ranges of $34.9^{\circ} \mathrm{c}$ to $41^{\circ} \mathrm{C}$ and $13^{\circ} \mathrm{C}$ to $16^{\circ} \mathrm{C}$ respectively. Total annual rainfall is about 700mm (Mamman et al., 2000).

\subsection{Source, Processing Method and Cost of Test Ingredient}

The fresh bitter kola seeds were purchased from a local market (Shagon Goro) in Sokoto South Local government area of Sokoto State- Nigeria. Bitter kola seeds were sliced, sundried. The soft brown testae were then removed before grinding into powdered form. The cost of IKg dried ground bitter kola as at the time of the research was Two Thousand Two Hundred and Twenty Two Nigerian Naira (\$2,222).

\subsection{Experimental Diets}

Three diets were formulated for the experiment. Diet one served as the control (without bitter kola) for diet two and three $5 \mathrm{~g} / \mathrm{kg}$ diet and $10 \mathrm{~g} / \mathrm{kg}$ diet dried ground bitter kola were added respectively. The composition of the diets is as shown in table 1.

\subsection{Experimental Birds and General Flock Management}

Sixty-three (63) day old broiler chicks of mixed sexes Marshall Strain were used in a completely randomized design. The birds were divided into three treatment groups with 21 birds per treatment. Each treatment was also replicated 3 times with 7 birds per replicate. The chicks were brooded on deep litter using 200 watt bulbs, flat plastics feeders and shallow drinkers for three weeks. The birds were fed the experimental diets starter mash for four weeks. Feed and water were provided ad-libitum. The birds were vaccinated against gumboro disease at first and third weeks of age as first and second doses respectively. Lasota vaccine was administered at the fourth week of age.

Table 1. Ingredient Compositions of Diets for Broiler Starters

\section{Diets}

Ingredient(s)

\begin{tabular}{|c|c|c|c|}
\hline & BK 0 & BK 5 & BK 10 \\
\hline Maize & 49 & 49 & 49 \\
\hline Wheat bran & 9 & 9 & 9 \\
\hline Groundnut Cake & 37.1 & 37.1 & 37.1 \\
\hline Bone meal & 2.5 & 2.5 & 2.5 \\
\hline Limestone & 1 & $\overline{1}$ & 1 \\
\hline
\end{tabular}




\begin{tabular}{|c|c|c|c|}
\hline Salt & 0.25 & 0.25 & 0.25 \\
\hline${ }^{*} \mathrm{M} \& \mathrm{~V}$ Premix & 0.25 & 0.25 & 0.25 \\
\hline Lysine & 0.5 & 0.5 & 0.5 \\
\hline Methionine & 0.4 & 0.4 & 0.4 \\
\hline Total & 100 & 100 & 100 \\
\hline$\overline{C o s t / K g} \operatorname{diet}(\#)$ & 109.65 & 120.76 & 131.87 \\
\hline \multicolumn{4}{|l|}{ Calc.Nutr. Analyses } \\
\hline $\mathrm{ME}(\mathrm{Kcal} / \mathrm{Kg})$ & 2830 & 2830 & 2830 \\
\hline Crude Protein (\%) & 24 & 24 & 24 \\
\hline Ether Extract (\%) & 4.5 & 4.5 & 4.5 \\
\hline Crude Fibre (\%) & 3.6 & 3.6 & 3.6 \\
\hline Lysine (\%) & 1.03 & 1.03 & 1.03 \\
\hline Methionine (\%) & 0.68 & 0.68 & 0.68 \\
\hline $\mathrm{Ca}(\%)$ & 1.36 & 1.36 & 1.36 \\
\hline Av. P (\%) & 0.52 & 0.52 & 0.52 \\
\hline
\end{tabular}

Animal care ${ }^{\circledR}$ supreme broiler starter mineral vitamin premix contain per Kg diet: Vit A: 20,000 i.u; Vit D3: 5,000 i.u.; Vit E: 50mg; Vit K3: 4.2mg; Folic acid: $1.67 \mathrm{mg}$; Niacin: 66.7mg; Calpan: 16.7mg; Vit B2: 8.3mg; Vit B12: 0.03mg; Vit B1: 3.3mg; Vit B6: 5.8mg; Biotin: 0.13mg; Antioxidant: 208mg; Cobalt: 0.42mg; Selenium: 0.42mg; Iodine: 2mg; Iron: 66.7mg; Manganese: 117mg; Copper: 13mg; Zinc: 100mg; Choline Chloride: $333 \mathrm{mg}$

\subsection{Data Collection}

At the onset of the experiment for each replicate, mean initial body weight of the birds were measured and recorded. Feed intake and body weights were measured and recorded weekly. Mortality was recorded as it occurs, weight gain, average daily weight gain, feed intake, average daily feed intake, feed gain ratio, cost of feed per $\mathrm{kg}$ gain were calculated.

\subsection{Data Analysis}

The data generated from the experiment was analyzed using paired t-test of the SPSS version 17 (SPSS, 2005) statistical package to compare the treatments (BK 0 and BK 5; BK 0 and BK 10 ; and BK 5 and BK 10).

\section{Results}

Results of the performance of broiler chicks fed supplementary dietary dried ground bitter kola are as shown in tables 2, 3 and 4. Comparison of broilers without dietary bitter kola (BK 0 ) and those with $5 \mathrm{~g} / \mathrm{Kg}$ ( BK 5) dietary bitter kola showed that there were no differences $(\mathrm{P}>0.05)$ in all the parameters analyzed except for feed-gain ratio (FGR) and cost of feed per $\mathrm{kg}$ gain (CFG). The FGR was lower (better) in birds fed BK 5 diet. Also lower CFG was obtained from birds fed the BK 5 diet. Comparison of broilers on BK0 and BK 10 diets showed that there were differences $(\mathrm{P} \leq 0.05)$ in terms of final weight $(\mathrm{FW})$, weight gain $(\mathrm{WG})$ and average daily weight gain (ADWG). Birds on $10 \mathrm{~g} / \mathrm{Kg}$ diet bitter kola supplementation had higher FW, WG and ADWG. The FGR was also slightly better $(\mathrm{P}>0.05)$ in broilers on BK 10 where as the CFG was slightly better $(\mathrm{P}>0.05)$ in birds fed BK0. Comparison of birds 
fed BK 5 and BK 10 diets revealed no differences $(\mathrm{P}>0.05)$ in all the performance parameters analyzed. However birds on BK 10 diet had slightly higher ( $>>0.05$ ) FW, WG and ADWG. No differences $(\mathrm{P}>0.05)$ exists in terms of percentage mortality for all the treatments comparison.

Table 2. Comparison of BK0 and BK5 Treatments on the Performance of Broiler chicks

\begin{tabular}{|c|c|c|c|c|}
\hline Parameter & BK0 & BK5 & $\mathbf{P}$ & Lev. of Sig. \\
\hline Initial weight $(\mathrm{g})$ & 43 & 43 & - & $\overline{\mathrm{NS}}$ \\
\hline Final weight $(\mathrm{g})$ & 708.88 & 766.66 & 0.31 & $\mathrm{NS}$ \\
\hline Weight Gain (g) & 665.88 & $\overline{723.66}$ & $\overline{0.31}$ & $\overline{\mathrm{NS}}$ \\
\hline$\overline{\mathrm{ADWG}(\mathrm{g})}$ & 23.78 & 25.84 & 0.31 & $\overline{\mathrm{NS}}$ \\
\hline$\overline{\text { Feed Intake }(\mathrm{g})}$ & 1233.33 & 1143.33 & $\overline{0.33}$ & $\overline{\mathrm{NS}}$ \\
\hline$\overline{\mathrm{ADFI}(\mathrm{g})}$ & $\overline{44}$ & 40.83 & $\overline{0.34}$ & $\overline{\mathrm{NS}}$ \\
\hline Feed-gain ratio & $1.86^{\mathrm{a}}$ & $1.55^{\mathrm{b}}$ & 0.05 & * \\
\hline$\overline{\mathrm{CF} / \mathrm{Kg} \text { gain }(\mathrm{N})}$ & $203.95^{\mathrm{a}}$ & $187.58^{b}$ & $\overline{0.04}$ & * \\
\hline Mortality (\%) & 9.48 & 14.2 & $\overline{0.57}$ & $\overline{\mathrm{NS}}$ \\
\hline
\end{tabular}

Table 3. Comparison of BK0 and BK10 Treatments on the Performance of Broiler Chicks

\begin{tabular}{|c|c|c|c|c|}
\hline Parameter & BKO & BK10 & $\mathbf{P}$ & Lev. of Sig. \\
\hline Initial weight (g) & 43 & 43 & - & $\mathrm{NS}$ \\
\hline Final weight $(\mathrm{g})$ & $708.89^{b}$ & $746.67^{\mathrm{a}}$ & 0.04 & $*$ \\
\hline Weight Gain $(\mathrm{g})$ & $665.89^{b}$ & $703.67^{\mathrm{a}}$ & $\overline{0.04}$ & * \\
\hline ADWG (g) & $23.78^{b}$ & $25.13^{\mathrm{a}}$ & 0.04 & $*$ \\
\hline Feed Intake $(\mathrm{g})$ & 1233.33 & 1230 & 0.25 & $\mathrm{NS}$ \\
\hline$\overline{\mathrm{ADFI}(\mathrm{g})}$ & 44.04 & 43.93 & 0.25 & $\overline{\mathrm{NS}}$ \\
\hline Feed-gain ratio & 1.86 & 1.75 & 0.06 & $\mathrm{NS}$ \\
\hline $\mathrm{CF} / \mathrm{Kg}$ gain $(\AA)$ & 203.95 & 230.34 & 0.06 & $\mathrm{NS}$ \\
\hline Mortality (\%) & 9.49 & 9.49 & 1.00 & $\overline{\mathrm{NS}}$ \\
\hline
\end{tabular}


Table 4. Comparison of BK5 and BK10 Treatments on the Performance of Broiler Chicks

\begin{tabular}{|c|c|c|c|c|}
\hline Parameter & BK5 & BK10 & $\mathbf{P}$ & Lev. of Sig. \\
\hline Initial weight (g) & 43 & $\overline{43}$ & - & $\overline{\mathrm{NS}}$ \\
\hline Final weight (g) & 766.67 & 746.67 & $\overline{0.06}$ & $\overline{\mathrm{NS}}$ \\
\hline Weight Gain (g) & 723.67 & 703.67 & $\overline{0.06}$ & $\overline{\mathrm{NS}}$ \\
\hline ADWG (g) & 25.84 & 25.13 & 0.06 & $\mathrm{NS}$ \\
\hline Feed Intake (g) & 1143.33 & 1230.00 & 0.86 & $\mathrm{NS}$ \\
\hline$\overline{\mathrm{ADFI}}(\mathrm{g})$ & 40.83 & 43.93 & $\overline{0.86}$ & $\overline{\mathrm{NS}}$ \\
\hline Feed-gain ratio & 1.55 & 1.75 & $\overline{0.53}$ & $\overline{\mathrm{NS}}$ \\
\hline$\overline{\mathrm{CF} / \mathrm{Kg} \text { gain }(\mathrm{N})}$ & 187.58 & 230.24 & $\overline{0.44}$ & $\overline{\mathrm{NS}}$ \\
\hline Mortality (\%) & $\overline{14.27}$ & 9.49 & 0.57 & $\overline{\mathrm{NS}}$ \\
\hline
\end{tabular}

${ }^{\mathrm{ab}}$ Mean values on the same row with different superscripts differ significantly $(\mathrm{P}<0.05)$. NS= Not significant. * Significant at $5 \%$ level. ADWG $=$ Average Daily Weight Gain. ADFI= Average Daily Feed Intake. $\mathrm{CF}=$ Cost of Feed. $\$=$ Nigerian Naira.

\section{Discussion}

The results from this experiment indicate that broilers performed better in terms of FW, WG, ADWG, FGR and CFG when dried bitter kola was added to their diets. Better FGR obtained from broilers fed dried bitter kola diet could be compared with the work of Adedeji et al., (2006) who obtained highest $(\mathrm{P}<0.05)$ feed efficiency from broiler chicks fed $25 \mathrm{~g}$ per $\mathrm{Kg}$ diet dried bitter kola over other broilers without bitter kola in their diets. Adedeji et al., (2008) also obtained better $(\mathrm{P}<0.05)$ hen day production and albumen weight from hens fed $10 \mathrm{~g} / \mathrm{Kg}$ diet dried bitter kola than those on the control treatment and those on treatments with bitter kola supplementation below and above $10 \mathrm{~g} / \mathrm{Kg}$ diet. Also research using Citrullus colocynthis (bitter apple or bitter cucumber) seed meal which is also a phytogenic on broilers revealed higher $(\mathrm{p}<0.05)$ body weight in birds fed the seed meal than those on the control diet. FGR was also better $(\mathrm{p}<0.01)$ in broilers fed the seed meal than those on the control diet (Sayda et al., 2012).

In addition the better weight gain obtained from broilers fed dried bitter kola in this study could be compared with the work of (Dada and Ikuerowo, 2009) who reported that fish fed $1 \mathrm{~g} / \mathrm{kg}$ diet ethalonic extract of bitter kola had best $(\mathrm{P}<0.05)$ weight gain than those fed the control diet and those fed $0.25,0.5$ and $2 \mathrm{~g} / \mathrm{kg}$ diet ethanolic extract of bitter kola. Osifo et al., (2011) administered oral suspension of dried bitter kola to rabbits at 1200, 1500 and $1800 \mathrm{mg} / \mathrm{kg}$ body weight and observed significantly $(\mathrm{p}<0.05)$ lower body weights from rabbits administered 1500 and $1800 \mathrm{mg} / \mathrm{Kg}$ body weight oral suspension of dried bitter kola. There were no differences in terms of body weights between rabbits on the control diet and those administered $1200 \mathrm{mg} / \mathrm{Kg}$ body weight. This result is contrary to the result obtained in this study possibly because in this study the bitter kola seed powder was used rather than the extract, the amount of the bitter kola administered to the animals couple with the variation in the species of the animals also differs. On the other hand, enhanced growth performance was also reported in poultry (Adedeji et al., 2006b) and rats (Oluyemi et al., 2007) fed diets 
containing bitter kola extracts. All the mortalities that occurred in this study could not be related to any specific cause, as such were assumed to have occurred by chance.

\section{Conclusions}

Though, the possible mode of action of bitter kola was not explored in this study. It is concluded that sundried ground bitter kola must have some active components that might have enhanced the physiology of the birds that fed on it to give them their superior performances. Also, $5 \mathrm{~g} / \mathrm{Kg}$ diet dried ground bitter kola can be used in broiler starter diets in order to have improved FW, FGR and better CFG. Further research should be conducted to explore the possible mode of action of $5 \mathrm{~g} / \mathrm{Kg}$ diet dried ground bitter kola on the physiology of broiler birds.

\section{References}

Adedeji,S .O., Farinu, O. G., Ameen, A. S., \& Olayemi, T. B. (2006b). J. Anim. Vet Adv. 5(3): 191 -193. Effects of Bitter Kola ( Garcinia kola) as Growth Promoter in Broiler Chicks from Day Old to Four Weeks Old. Journal of Animal and Veterinary Advances, 5, 191-193. Retrieved from http://medwelljournals.com/abstract/?doi=javaa.2006.191.193.

Adedeji, O. S., Farinu, G.O., Olayeni, T. B., Ameen, S. A., \& Babatunde , G. M (2008). Perfomance and Egg Quality Parameters of Laying Hens Fed Different Dietary Inclusion Levels of Bitter Kola (Garcinia kola) Research Journal of Poultry Sciences, 2, 75-77. Retrieved from http://medwelljournals.com/abstract/doi=rjpscience.2008.75.77.

Adedeji, O. S., Farinu, G. O., Ameen, S. A., \& Olayeni, T. B. (2006). The effects of dietary bitter kola (Garcinia kola ) Inclusion on body weight, haematology and survival rate of pullets chicks. J. Anim. Vet. Adv., 5(3), 184-187. Retrieved from http://medwelljournals.com/abstract/?doi=javaa.2006.184.187.

Adegboye, M . F., Akinpelu, D. A., \& Okoh, A. I. (2008). The bioactive and phytochemical properties of Garcinia kola (Heckel) seed extract on some pathogens. African Journal of Biotechnology Vol. 7 (21), pp. 3934-3938. Retrieved from http://www.academicjournals.org/AJB. http://dx.doi.org/10.5897/AJB08.586.

Adesuyi, A.O., Elumm, I. K., Adaramola, F. B., \& Nwokocha, A .G. M. (2012). Nutritional and Phytochemical Screening of Garcinia kola. Advance Journal of Food Science and Technology, 4(1), 9-14.

Botsoglou, N. A., Christaki, E., Florou-Paneri, P., Gieannenas, I., Papageorgiou, G., \& Spais, A. B. (2004). The effect of a mixture of herbal essential oils or $\alpha$-tocopheryl acetate on performance parameters and oxidation of body lipid in broilers. S. Afr. J. Anim. Sci., 34, 52-61.

Cross, D. E., McDevitt, R. M., Hillman, K., \& Acamovic, T. (2007). The effect of herbs and their associated essentialoils on performance, dietary digestibility and gut microflora in chickens from 7 to 28 days of age. Br Poult. Sci. 48, 496-506.

Dada, A. A., \& Ikuerowo, M. (2009). Effects of ethanolic extracts of Garcinia kola seeds on 
growth and haematology of catfish (Clarias gariepinus) broodstock. African Journal of Agricultural Research, 4(4), 344-347. http://www.academicjournals.org/AJAR.

Ebana, R. U., Madunagu, B. E., Ekpe, E. D., \& Otung, I. N. (1991). Microbiological exploitation of cardiac glycosides and alkaloids from Garcinia kola, Borreria ocymoides, Kola nitida and Citrus auratifolia. J. Appl. Bacteriol. 71(5), 398-401. http://dx.doi.org/10.1111/j.1365-2672.1991.tb03807.x.

Ertas,O.N., Güler,T., Çiftçi, M., DalkIlIç, B., \& Simsek, Ü. G. (2005). The effect of an essential oil mix derived from oregano, clove and anise on broiler performance. Int. J Poult. Sci, 4(11), 879-884

Flint, J. F., \& Garner, M. R. (2009). Feeding beneficial bacteria: A natural solution for increasing efficiency and decreasing pathogens in animal agriculture. J Appl. Poult. Res., 18, 367-378. http://dx.doi.org/10.3382/japr.2008-00133

Gill, C. (1999). Herbs and plant extracts as growth enhancers. Feed Int., 20(4), 20-23.

Humphrey, B. D, Huang, N., \& Klasing, K .C (2002). Rice expressing lactoferrin and lysozyme has antibiotic-like properties when fed to chick. J. Nutr., 132, 1214-1218.

Ibekwe, H .A., \& Orok, E .E. (2010). Proximate Composition of Aframomum Melegueta Seeds, Garcinia kola Seeds and Growth Performance of Broiler ChicksTreated with Powders from These Seeds. International Journal of Poultry Science, 9(12), 1152-1155.

Iwu, M .M. (1993). Hand Book of African Medicinal Plants. CRC. Press; London, 183-184.

Iwu, M .M., Igboko, A .O., \& Tempesta, M. S. (1990). Antidiabetic and aldose reductase activities of biflavanones of Garcinia kola. Fitoterapia, LXi(1), 178.

Lee, K.W., Everts, H., Kappert, H.J., Frehner, M., Losa, R., \& Beynen, A. C. (2003). Effects of dietary essential oil components on growth performance, digestive enzymes and lipid metabolism in female broiler chickens. Br. Poult. Sci, 44, 450-457.

Lovkova, M. Y., Buzuk, G. N., Sokolova, S .M., \& Kliment'eva, I. (2001). Chemical features of medicinal plants (Review). Appl Biochem. Microbiol. 37, 229-237.

Mamman, A. D, Onyebanji, J .O., \& Peters, S. (2000). Nigeria A people united, A future Assured ( survey of states ) Vol. 2 Gabinho publishing Co. Ltd. Calabar, Nigeria.

Odebunmi, E. O., Oluwaniyi, O .O., Awolola, G .V., \& Adediji, O .D. (2009). Proximate and nutritional composition of kola nut (Cola nitida), bitter cola (Garcinia cola) and alligator pepper (Afromomum melegueta). African Journal of Biotechnology, 8(2), 308-310. http://www.academicjournals.org/AJB

Okunji,C .O., Tantalia, A.W., Hicks, R. P., Iwu, M .M., \& Skanchy, D. J. (2002). Capillary electrophoresis determination of biflavonones from Garcinia kola in three traditional African medicinal formulations. Plant Med., 68, 440-444.

Okunji, C .O., \& Iwu, M. M. (1991). Molluscidal activity of Garcinia Kola biflavonones. 
Fitoterapia, 67, 74-76.

Oluwole, F .S., \& Obtatomi, A .B (1991). The effect of Garcinia kola seed on Gastric acid secretion in albino rats. Nig. J. Physio Sci, 8, 75-80.

Oluyemi, A .K., Omotuyi, O. I., Jimoh, R .O., Adesanya, A. O., Saalu, C. L., \& Josiah, L. S (2007). Biotechnol. Appl. Biochem, 46, 69 -72.

Onayade, O A., Looman, A. M. G., Scheffer, J .J .C., \& Gbile, Z .O. (1998). Lavender lactone and other volatile constituents of the oleoresin from seeds of Garcinia Kola Hechel. Flavour and Fragrance., 13(6), 409-412. http://dx.doi.org/10.1002/(SICI)1099-1026(199811/12)

Osifo, U .C., Akpamu,U., Otamere, H. O., \& Ekhator, C. N. (2011). A murine model study on the effect of Garcinia kola on body weight. Archives of Applied Science Research, 2011, 3(5), 526-531. Retrieved from http://scholarsresearchlibrary.com/archive

Plowden, C. C. (1992). A manual of plants names $3^{\text {rd }}$ edition., London geroge Ltd. pp239.

Sayda,A .M., Ali, H., Abdalla, O., \& Mohammed, A .E. (2012). Citrullus Colocynthis (Handal) Seed Meal As A Natural Feed Supplementation In Broiler Chickens' Diets. Egypt. Poult. Sci. (32) (II), (237-246).

SPSS (2005). Statistical Package for the Social Sciences version 17.

Terashima, K., Kondo, Y., Aqil, M., Waziri, M (1999). A study of biflavanones from the stem of Garcinia kola. Heterocycles, 50(1), 283-290. DOI: 10.3987/COM-98-S(H)40.

Wenk, C. (2000). Why all the discussion about herbs? Proc. Alltech's $16^{\text {th }}$ Ann. Symp. Biotechnol. in the Feed Industry. Ed. Lyons, T.P., Alltech Tech. Publ., Nottingham, University Press, Nicholasville, KY. pp. 79-96.

WHO (2002). World Health Organization: Use of antimicrobials outside human medicine and resultant antimicrobial resistance in humans. https://apps.who.int/inf-fs/en/fact268.html

Williams, P., \& Losa, R (2001). The use of essential oils and their compounds in poultry nutrition. World's Poult 17, 14-5 Arch Tierz 53 (2010) 3, 350-359.

Windisch, W., Schedle, K., Plitzner, C., \& Kroismayr, A. (2008). Use of phytogenic products as feed additives for swine and poultry. J. Anim Sci., 86, E140-E148. http://dx.doi.org/10.2527/jas.2007-0459.

\section{Copyright Disclaimer}

Copyright reserved by the author(s).

This article is an open-access article distributed under the terms and conditions of the Creative Commons Attribution license (http://creativecommons.org/licenses/by/3.0/). 